\title{
KEARIFAN LOKAL POPENE'E DALAM PERSPEKTIF PENDIDIKAN ISLAM PADA MASYARAKAT ETNIK TIALO TOMINI DI SULAWESI TENGAH
}

\author{
Hamlan Andi Baso Malla \\ Institut Agama Islam Negeri Palu \\ E-mail: hamlan@iainpalu.ac.id
}

\section{Markarma}

Institut Agama Islam Negeri Palu

E-mail: andi@gmail.com

\section{Munifa}

Institut Agama Islam Negeri Palu

E-mail:munifa@gmail.com

\begin{tabular}{|c|c|c|}
\hline Received & Revised & Accepted \\
\hline 4 July $\mathbf{2 0 2 1}$ & 2 Agustus 2021 & 20 September 2021 \\
\hline
\end{tabular}

\section{LOKAL WISDOM OF PAPENE'E BASED ON ISLAMIC EDUCATION PERSPECTIVE TO SOCIETY OF TIALO TOMINI ETHNIC IN SULAWESI TENGAH}

\begin{abstract}
This paper aims to find out the values of Islamic education in the Popene'e marriage custom of the Tialo Tribe in Tomini District. In this study, the author uses qualitative descriptive research, which describes in-depth cultural and interpretive studies about the object under study. Based on these data, the results of this study reveal that: The values of Islamic education in the marriage custom of the Tialo tribe popene'e contain several values including the value of monotheism, sharia, morals, and social values. These four values are in the marriage custom of the Popene'e Tialo tribe in the Tomini sub-district. The marriage custom of the popene'e tialo tribe is very relevant to Islamic teachings which are sourced from the Qur'an and hadis. It is closely related to the concept of education or Islamic teachings in the popene'e marriage custom of the Tialo tribe against the background of the early history of the existence of Islam in the Tomini District area. The first stage to the end according to the author does not conflict with Islamic religious education, the relevance between the two is illustrated in each stage of the implementation of the five stages of the Tialo tang popene'e marriage custom. According to the view of Islamic religious education, the marriage custom of the Tialo tribe popene'e is referring to the concepts of Islamic educational values which are packaged in such a way in the form of customs without leaving the foundation of the Qur'an and hadis.
\end{abstract}

Keywords: local wisdom, Popene'e rituals, and Islamic education values. 


\begin{abstract}
Abstrak
Tulisan ini betujuan untuk mengetahui Nilai-nilai Pendidikan Islam dalam Adat pernikahan Popene'e Suku Tialo di Kecamatan Tomini. Dalam penelitian ini, penulis menggunakan jenis penelitian deskriptif kualitatif, yakni memaparkan secara mendalam kajian budaya dan interpretatif tentang objek yang diteliti. Berdasarkan data tersebut maka hasil penelitian ini mengungkapkan bahwa : Nilai-nilai pendidikan islam dalam adat pernikahan popene'e suku tialo ini mengandung beberapa nilai diantaranya nilai tauhid, syariat, akhlak, dan nilai sosial. ke empat nilai tersebut ada dalam adat pernikahan popene'e suku tialo di kecamatan tomini. Adat pernikahan popene'e suku tialo sangat relevan dengan ajaran Islam yang bersumber pada Al-Qur'an dan hadist. Sangat berkaitan dengan konsep pendidikan atau ajaran Islam dalam adat pernikahan popene'e suku tialo dilatar belakangi oleh sejarah awal mula keberadaan Islam di wilayah Kecamatan Tomini. Tahapan pertama sampai akhir menurut penulis tidak bertentangan dengan pendidikan agama Islam relevansi diantara keduanya tergambar dalam setiap tahapan pelaksanaan adat pernikahan popene'e suku Tialo tang berjumlah lima tahap. Menurut pandangan pendidikan agama Islam adat pernikahan popene'e suku tialo ini adalah mengacuh pada konsep-konsep nilai-nilai pendidikan islam yang dikemas sedemikian rupa dalam bentuk adat istiadat dengan tidak meningalkan landasan Al-Qur'an dan hadist.
\end{abstract}

Kata kunci: kearifan lokal, ritual Popene'e, dan nilai-nilai pendidikan Islam

\title{
Pendahuluan
}

Dalam kehidupan bermasyarakat terdapat nilai-nilai luhur yang dijadikan sebagai pedoman perilaku oleh setiap anggota masyarakat yang berlaku di lingkungan masyarakat. Nilai yang lahir, terbentuk atas kesepakatan berdasarkan budaya dalam kehidupan mayarakat disebut nilai sosial. Nilai sosial sangat beragam, seperti nilai moral, nilai religi, nilai estetika (keindahan), dan sebagainya. ${ }^{1}$ Secara filosofi, nilai disebut dengan etika. Etika sering disebut filosofi nilai yang mengkaji nilai-nilai moral secara tolak ukur tindakan dan perilaku manusia dalam berbagai aspek kehidupannya. Sumber-sumber etika dan moral bisa merupakan hasil pikiran, adat istiadat, atau tradisi, ideologi bahkan dari agama.

Pendidikan Islam sebagai usaha orang dewasa muslim yang bertakwa secara sadar mengarahkan dan membimbing pertumbuhan serta perkembangan fitrah (kemampuan sadar) anak didik melalui ajaran Islam ke arah titik maksimal pertumbuhan dan kekurangannya. Dari kedua pengertian di atas yaitu pengertian nilai dan pendidikan Islam dapat diambil definisi bahwa nilai- nilai pendidikan Islam adalah kumpulan dari prinsip-prinsip hidup yang saling terkait yang berisi ajaranajaran I slam guna memilihara dan mengembangkan fitrah manusia serta sumber daya manusia yang ada padanya menuju terbentuknya manusia seutuhnya (insan kamil) sesuai dengan norma atau ajaran Islam. ${ }^{2}$ Uraian tentang nilai-nilai pendidikan Islam, penulis megemukakan beberapa pendapat diantaranya sebagai berikut:

Rukaiyah M. Berpendapat "nilai-nilai pendidikan Islam adalah ada pula determinasi yang terdiri dari cara pandang, aturan dan norma yang ada pada

\footnotetext{
${ }^{1}$ Ibid,3.

${ }^{2}$ Sjarkawi, Pembentukan Kepribadian Anak, (PT Bumi Aksara, 2008),27
} 
pendidikan Islam yang selalu berkaitan dengan akidah ibadah syariah dan akhlak". 3

Dengan demikian dapat dipahami bahwa nilai-nilai pendidikan islam adalah ciri khas, sifat yang melekat yang terdiri dari aturan dan cara pandang yang dianut oleh agama islam. Dunia pendidikan akhir-akhir ini tidak terlepas dari kemajuan diberbagai bidang, baik sains, teknologi, komunikasi maupun bidang lainya. Kemajuan-kemajuan tersebut tidak semuanya memberikan nilai manfaat pada generasi muda, namun tentu saja banyak sisi negatif yang diakubatkan oleh seiring dengan kemajuan zaman. Kalau setiap orang tidak waspada terhadap akses negatif kemajuan zaman, maka secara langsung kemajuan zaman itu berpengaruh juga terhadap nilai-nilai, adat budaya, maupun norma-norma yang berlaku dalam masyarakat.

Menurut S. Trimo dalam Chalijah Hasan mengatakan:

"kemajuan dan perkembangan teknologi yang telah berhasil membuat dunia semakn kecil, membawa pengaruh yang besar pada norma-norma dan system nilai masyarakat, perilaku manusia organisasi, struktur keluarga, mobilitas masyarakat, kebijakan pemerintah, dan sebagainya". ${ }^{4}$

Komponen nilai-nilai Islam yaitu nilai tauhid, nilai syariat, nilai akhlak, nilai sosial. Setelah istilah nilai didefinisikan, kemudian penulis akan mendefinisikan pengertian dari pendidikan Islam. Sebelum mendefinisikan pengertian dari pendidikan Islam faktanya bahwa sering. dijumpai ada kerancuan dalam penggunaan istilah "Pendidikan Islam” dengan "Pendidikan Agama Islam".

Achmadi menjelaskan pengertian pendidikan agama Islam yaitu sebagai usaha yang lebih khusus ditekankan untuk mengembangkan fitrah keberagamaan subjek peserta didik agar mampu memahami, menghayati dan mengamalkan ajaranajaran Islam. ${ }^{5}$

Tujuan pendidikan Islam harus berorientasi kepada hakikat pendidikan Islam itu sendiri yang meliputi : pertama; tentang tujuan dan tugas hidup manusia, penekanannya adalah bahwa manusia hidup bukannkebetulan dan sia-sia, sehingga peserta didik bisa melaksanakan tugas dan tanggung jawabnya untuk mengabdi kepada tuhan sebaik-baiknya. Kedua; rumusan tujuan tersebut harus sejalan dan memperhatikan sifat-sifat dasar atau fitrah manusia tentang nilai, bakat, minat dan sebagainya yang akan membentuk karakter peserta didik. Ketiga, tujuan pendidikan Islam sesuai dengan tuntutan masyarakat dengan tidak menghilangkan nilai-nilai lokal yang bersumber dari budaya dan nilai-nilai ilahiyah yang bersumber dari wahyu tuhan demi menjaga keselamatan dan peradaban umat manusia. Keempat ; tujuan pendidikan Islam harus sejalan dengan keinginan manusia untuk mencapai kebahagiaan hidup. Yakni pendidikan Islam tidak sematamata mementingkan

\footnotetext{
${ }^{3}$ Rukaiyah M, Konsep Nilai dalam Pendidikan Islam, (Padangsidimpuan: Makalah STAIN Padangsidimpuan, 2006), 12

${ }_{5}^{4}$ Chalijah Hasan, Dimensi-Dimensi Pendidikan, (Surabaya: Al-Ikhlas), 201

5 Achmadi, Tujuan Pendidikan Islam, (At-Tadzkiyyah: Jurnal Pendidikan Islam, 6 November 2015).122
} 
urusan dunia tetapi adanya keselarasan antara kehidupan dunia dan kehidupan akhirat dikemudian hari. ${ }^{6}$

Pendidikan Islam adalah usaha orang dewasa muslim yang bertakwa secara sadar mengarahkan dan membimbing pertumbuhan serta perkembangan fitrah (kemampuan sadar) anak didik melalui ajaran Islam ke arah titik maksimal pertumbuhan dan kekurangannya. Dari kedua pengertian di atas yaitu pengertian nilai dan pendidikan Islam dapat diambil definisi bahwa nilai- nilai pendidikan Islam adalah kumpulan dari prinsip-prinsip hidup yang saling terkait yang berisi ajaranajaran islam guna memilihara dan mengembangkan fitrah manusia serta sumberdaya manusia yang ada padanya menuju terbentuknya manusia seutuhnya (insan kamil) sesuai dengan norma atau ajaran Islam. ${ }^{7}$

Sedangkan Pendidikan Islam menurut bahasa ada tiga kata yang digunakan dalam pengertian pendidikan islam yaitu "at-tarbiyah, al-ta"lim, al-ta"dib. Ketiga kata tersebut memiliki makna yang saling berkaitan saling cocok untuk pemaknaan pendidikan dalam islam. Ketiga kata tersebut mengandung makna yang amat dalam, menyangkut manusia dan masyarakat serta lingkungan yang dalam hubungan dengan Tuhan saling berhubungan antara satu dengan yang lain.

Adat popene'e suku tialo ini sangat relevan dengan ajaran Islam yang bersumber dari Al-Qur'an dan Hadits. Sumber ajaran tersebut sangat erat dengan konsep pendidikan atau ajaran Islam dalam adat popene'e suku tialo. Relevansi keduanya sangat tergambar dalam setiap tahapan pelaksanaan adat popene'e suku tialo yang berjumlah delapan tahap. Dalam kontek pendidikan islam maka sumber etika dan nilai yang paling sahih adalah Al-qur'an dan Sunnah Nabi Saw dan kemudian di banggakan oleh hasil ijtihad para ulama. ${ }^{8}$ Nilai merupakan seperangkat kebiasaan atau aturan yang diakui kebenaranya oleh semua anggota masyarakat dalam rangka mencapai kehidupan masyarakat yang teratur. Nilai adalah sesuatu yang dipentingkan manusia sebagai subjek, menyangkut segala sesuatu yang baik atau yang buruk. Nilai sosial sangat berperan penting dalam kehidupan yaitu untuk mengatur pola kehidupan masyarakat agar pola perilaku yang ditunjukkan seimbang, tidak merugikan, serta tidak menimbulkan ketidak adilan. Apa bila nilai sosial diterapkan dengan baik, maka akan menghasilkan masyarakat yang tertib dan teratur. Hubungan antara pendidikan islam ialah untuk menentramkan hati, ketenangan jiwa dan ketenangan batin. Sesungguhnya pernikahan itu merupakan hubungan dua hati yang sangat dahsyat dan Allah mengingatkan keduanya untuk memberikan ketentraman dan ketenangan datin dalam sebuah rumah tangga yang penuh kasih sayang dan kehangatan.

Adat pernikahan di Indonesia banyak sekali macam ragamnya. Setiap suku bangsa memiliki adat pernikahan masing-masing. Diantara adat pernikahan itu ada yang hampir serupa terutama pada suku-suku yang berdekatan, tetapi ada pula yang sama sekali berlainan. Pada dasarnya, adat pernikahan bangsa Indonesia bertolak

\footnotetext{
6 Imam Syafe ei, “ tujuan pendidikan islam” ( At-Tadzkiyyah : Jurnal Pendidikan Islam, vol 6, November 2015), 152

${ }^{7}$ Sjarkawi, Pembentukan Kepribadian Anak, (Jakarta : PT Bumi Aksara, 2008), 27.

${ }^{8}$ Said Agil Husin Al Munawar, Aktualisasi Nilai-nilai Qur'an Dalam Sistem Pendidikan Islam, (PT Ciputat Press, 2005),3.
} 
dari anggota masyarakat bahwa pernikahan adalah suatu ikatan yang sakral dan merupakan salah satu sunnah kauniyah Allah SWT yang tidak bisa dihindari oleh manusia. ${ }^{9}$ Pernikahan bukan sekedar ikatan antara seorang laki-laki dan seorang perempuan tetapi juga merupakan proses penyatuan dua keluarga. Pernikahan merupakan ikatan sosial antra laki-laki dan perempuan yang akan membentuk hubungan untuk mencapain tujuan yang baik sesuai dengan syariat islam demi terciptanya keluarga sakinah, mawaddah dan warahmah. Pernikahan merupakan suatu cara yang ditetapkan oleh Allah SWT sebagai jalan bagi manusia untuk beranak, berkembang biak dan menjaga kelestarian hidupnya, setelah masingmasing pasangan siap melakukan perananya yang positif dalam mewujudkan tujuan perkawinan $^{10}$.

Kecamatan Tomini adalah suatu kelompok masyarakat yang mendiami sekitaran Kecamatan Tomini yang berada dipantai Timur Kabupaten Parigi Moutong Provinsi Sulawesi Tengah. Kecamatan Tomini sendiri memiliki dua sub- suku yaitu Suku Tialo dan Suku Lauje. Istilah Tomini merujuk kepada kelompok masyarakat yang berada di sekitar Kecamatan Tomini. Sedangkan di Kecamatan Tomini dihuni oleh beberapa kelompok masyarakat seperti Suku Tialo, Lauje, Bajau, Togian dan lain-lain. Tapi yang mengklaim diri sebagai penduduk asli didaerah Kecamatan Tomini adalah Suku Tialo, sehingga kedua suku inilah yang lebih sering disebut sebagai orang Tomini.

Masyarakat Tomini adalah mayoritas penganut agama islam sunni. Suatu aliran agama islam yang berpegang pada tradisi ortodoks yang kuat dan fanatik, tapi dalam praktik keseharian mereka adalah orang-orang terbuka dan ramah, serta bisa menerima kehadiran siapa saja dengan terbuka. Dalam mata pencaharian ekonomi Masyarakat Tomini sebagian hidup dengan menanam cengke dan kelapa, beberapa diantara mereka mencari nafkah sebagai pedagang dan juga ikut dalam kegiatan penebangan kayu disekitaran pemukiman mereka, beberapa yang lain melakukan kegiatan sebagai nelayan atau menggumpulkan hasil laut mereka seperti rumput laut, sedangkan sebagian orang Tomini yang tinggal didaerah pegunungan pada umumnya hidup sebagai petani., mereka menanam padi disawah atau ladang, dan juga membuka lahan kebun untuk tanaman jagung."

Sistem adat pernikahan Suku Tomini adalah seorang perantara merundingkan maskawin untuk mempelai perempuan yang tergantung status sosial perempuan tersebut. Salah satu adat dalam pernikahan suku tialo yang sampai saat ini masih dipegang erat dan selalu dilaksanakan pada saat adat pernikahan adalah adat popene'e. ${ }^{12}$

Popene'e adalah kunjungan pertama pengantin perempuan kerumah mertuanya (popene'e) bersama pengantin laki-laki. Popene'e ini sebagai simbol bukti penghargaan anak kepada orang tua, sekaligus menandai bahwa pihak

\footnotetext{
${ }^{9}$ Adil Abdul Mun'im Abu Abbas, Ketika Menikah Jadi Pilihan (Jakarta: Almahira, 2001) 9.

${ }^{10}$ Amir Syarifuddin, Hukum Perkawinan Islam di Indonesia, antara Fiqh Munakahat dan UndangUndang Pekawinan (Jakarta: kencana, Cet. III, 2009), 48

${ }^{11}$ Ibid, jam 01:30.

${ }^{12}$ Khairil Mayah, Adat Pernikahan Suku Tialo (diposting 2 Juni 2016 05:32) http://id.wikipedia.org/wiki/Suku-Tomini diakses (8 Desember 2018), Jam 01:00
} 
perempuan sudah merupakan bagian dari keluarga pihak laki-laki/suaminya. Prosesi popene'e merupakan hal yang penting dilakukan pada pelaksanaan pernikahan suku Tialo. Pelaksanaan prosesi ini dilakukan sehari setelah pernikahan. Pelaksanaan popene'e merupakan simbol tanggung jawab seorang suami dan istri serta simbol kasih sayang istri kepada keluarga suami.

Telah ada artikel penelitian yang mengungkap tradisi Prosesi Popene'e Suku Lauje dengan mengkaji dari sudut makna simbolik dalam prosesi adat tersebut. Penelitian ini menjelaskan bahwa Pelaksanaan popene'e merupakan simbol tanggungjawab seorang istri dan suami serta simbol kasih sayang istri kepada keluarga suami. Pelaksanaan popene'e adalah akhir dari serangkaian upacara yang terdapat di dalam upacara perkawinan suku Lauje. Prosesi popene'e terdapat 8 tahapan yaitu moyambute pangantinge, (monimbaluse, mombiase niu kangkai mongkologe, mombiase ayu), dan monesege longu pensae, mongunjae baki, mongkoni alat tuwahu njopa monja'ange pensae, meepa'anange, momongi do'a salamate dan terakhir mopooto. setiap tahapan dalam prosesi popene'e memiliki makna tersendiri, baik berupa tindakan, benda/perlengkapan yang digunakan, maupun mantra yang diucapkan dalam pelaksanaan prosesi tersebut ${ }^{13}$.

Masyarakat Suku Tialo di Kecamatan Tomini mayoritas penganut agama islam sehingga terjadi alkulturasi antara nilai-nilai ajaran islam dan budaya masyarakat setempat yang tidak bisa berdiri sendiri melainkan satu kesatuan yang tidak bisa dipisahkan dari kehidupan masyarakat Etnik Tialoa salah satunya dalam pelaksanaan penikahan. Untuk itu, tulisan ini betujuan untuk melihat Implementasi Nilai-nilai Pendidikan Islam dalam Adat pernikahan Popene'e Suku Tialo di Kecamatan Tomini.

\section{Metode Penelitian}

Penelitian ini menggunakan pendekatan kualitatif istilah kualitatif tidak hanya lazim dimaknai sebagai jenis data, tapi juga berhubungan dengan analisis data dan interpretasi atas objek kajian. Secara historis, implementasi penalitian kualitatif bermula dari pengamatan. Sebagai perbandingan, pada penelitian kualitatif, pengamatan berkenaan dengan pengukuran tingkatan dengan suatu ciri tertentu. Namun penelitian kualitatif menunjukkan pada segi alamiah yang dipertentangkan dengan jumlah. Maksudnya, penelitian kualitatif tidak dimaksudkan untuk mengadakan perhitungan secara kuantitas. Hal ini berbeda dengan pengamatan pada penelitian kuantitatif yang pengamatanya berdasarkan perhitungan persen, rata-rata, dan sebagai perhitungan statistik.

Menurut Bigdan dan Tailor metode penelitian kualitatif adalah prosedur penelitian yang menghasilkan data deskriptif kualitatif berupa kata-kata tertulis datu lisan dari orang-orangdan perilaku yang diamati. Metode penelitian ini sering disebut " Metode penelitian naturalistik" karena penelitianya dilakukan dengan kondisi alamiah. Sementara, menurut Kirk Miller, penelitian kualitatif adalah tradisi tertentu dalam ilmu pengetahuan sosial yang secara funda mental. Bergantung dari pengamatan pada manusia baik dalam kawasan maupun dalam peristilahanya. sedangkan menurut David William menuliskan bahwa penelitian kualitatif adalah

${ }^{13}$ Arifuddin, S., \& Palu, K. B. T. T. (2019). Makna Simbolik Dalam Prosesi Popene'e Suku Lauje Di Desa Tomini Utara Kec. Tomini Kab. Parigi Moutong. Jurnal Bahasa dan Sastra, 4(1), 53-67. 
pengumpulan data pada suatu latar alamiah dengan menggunakan metode alamiah dan dilaksanakan oleh orang atau peneliti yang tertarik secara alamiah. Dalam penjelasan lain Bogdan dan Taylor menerangkan bahwa penelitian kualitatif adalah reaksi dari tradisi yang berkaitan dengan positivisme dan postpositipisme yang berupaya melakukan kajian budaya dan interpretatif. ${ }^{14}$

Lokasi penelitian ini adalah di Kecamatan Tomini. Penulis memilih lokasi ini sebagai tempat penelitian antara lain karena di Desa ini merupakan salah satu jumlah penduduknya yang bersuku tialo yang melaksanakan adat popene'e suku tialo.

Di Kecamatan Tomini itu mudah dijangkau oleh peneliti sehingga dalam penelitian nanti akan memudahkan peneliti dalam memperoleh data karena desa Tomini barada dijalan Trans Sulawesi.

Kehadiran penulis dalam mengadakan penelitian deskriptif kualitatif sebagai upaya untuk melakukan penggalian data yang akurat dan objektif. Dalam penelitian ini penulis sebagai perencanaan instrumen, pelaksanaan pengumpulan data, manganalisis data sekaligus sebagai penulis hasil penelitian. Sebagai instrumen utama penelitian sebagai media pengumpulan data, sekaligus sebagai pengamatan langsung, pencatatan yang dilakukan terhadap objek-objek dilokasi kejadian atau berlangsungnya kejadian sehingga pengamatan berada bersama pada objek yang diteliti secara langsung.

Jenis dan sumber data dalam penelitian ini dapat dikategorikan menjadi dua, yaitu data primer dan sekunder. Data primer adalah jenis data yang didapatkan melalui pengamatan langsung berupa pengamatan berupa peristiwa pernikahan. Selain itu data primer juga diperoleh melelui wawancara dan narasumber atau informan yang benar-benar dapat mengerti dan memahami Nilai-nilai Pendidikan Islam dalam Adat Popene'e Suku Tialo Di Kecamatan Tomini. Adapun sumber atau informan penelitian ini adalah camat, ketua adat, imam, orang tua lakilaki/perempuan, dan masyarakat dan orang-orang yang paham dan mengetahui betul nilai-nilai pernikahan adat popene'e suku tialo tersebut. Data sekunder adalah data yang diperoleh melalui metode pengumpulan data dengan cara dokumentasi dan catatan yang berkaitan dengan objek penelitian. Adapun data sekunder yang dimaksud yaitu data berupa jumlah masyarakat, alat-alat yang digunakan dan segala cara yang digunakan dalam pernikahan adat popene'e suku tialo.

Pengumpulan data untuk penelitian ini, penulis menggunakan beberapa teknik pengumpulan data sebagai berikut: Teknik observasi yang digunakan adalah observasi langsung. Observasi langsung tersebut dilakukan dengan mekanisme yaitu penulis datang dan mengamati secara langsung bagaimana pelaksanaan Adat Popene'e Dalam Pernikahan Suku Tialo Di Kecamatan Tomini. penelitian yang digunakan dalam observasi langsung adalah pedoman dan alat tulis menulis untuk mencatat data yang didapatkan di lapangan. Penulis mengamati bahwa pelaksanaan adat popene'e suku tialo ini sangat relevan dalam pelaksanaan adat tersebut.

Interview atau wawancara dilakukan oleh dua pihak yaitu pewawancara (interviewer) yang mengajukan pertanyaan dan informan yang memberikan jawaban.

${ }^{14}$ Andi Prastowo, "Metode Penelitian Kualitatif" (Jogjakarta: AR-RUZZ MEDIA 2016), 21 
Wawancara dengan informan yang diwawancarai adalah camat, kepala adat, tokoh masyarakat, orang tua laki-laki/perempuan dan juga masyarakat yang paham dan mengetahui betul nilai-nilai pendidkan yang terkandung dalam adat popene'e. Adapun pertanyaannya yaitu: (1) Bagaimana adat popene'e suku tialo di Kecamatan Tomini (2) Apa yang diperlukan sebelum adat popene'e suku tialo dilaksanakan (3) Ada berapa tahapan dalam adat popene'e (4) Apakah relevan antar tahapan-tahapan dan tata cara adat popene'e suku tialo di Kecamatan Tomini (5) Bagaiman pandangan Islam tentang adat popene'e suku tialo di kecamatan Tomini (6) Nilainilai pendidikan apa saja yang terdapat dalam adat popene'e suku tialo diKecamatan Tomini. Tetapi tidak menutup kemungkinan peneliti dapat mengembangkan pertanyaan-pertanyaan itu agar mendapatkan informasi yang diperlukan sebagai penjelasan dari konsep yang telah diberikan. Teknik dokumentasi merupakan teknik pengumpulan data dengan meneelah dokumen penting yang menunjang kelengkapan data. dalam teknik pengumpulan data ini peneliti melakukan penelitian dengan menghimpun data yang relevan dari sejumlah dokumen resmi atau arsip penelitian yang dapat menunjang kelengkapan data penelitian serta dalam bentuk dokumen ini, peneliti juga menggunakan kamera sebagai bukti bahwa penelitian benar-benar dilakukan di lokasi yang dimaksud.

Setelah sejumlah data dan keterangan dikumpulkan, maka langkah selanjutnya adalah menganalisis data dengan menggunakan teknik analisis Reduksi Data, penajian data dan verifikasi data. Dalam kegiatan menverifikasi, penulis mengambil kesimpulan dengan mengacuh pada hasil reduksi data. Data-data yang terkumpul dari hasil wawancara, observasi dan dokumentasi, penulis pilih yang mana sesuai dengan judul dan membuang yang tidak perlu.

Pengecekan keabsahan data diterapkan dalam penelitian ini agar data yang diperoleh terjamin validitas dan kredibilitasnya, pengecekan keabsahan data dilakukan dengan triangulasi data Triangulasi dengan sumber, maksudnya membandingkan dan mengecek balik, derajat kepercayaan suatu informasi yang diperoleh melalui waktu dan alat yang berbeda. Hal ini dapat diperoleh dengan cara membandingkan data hasil pengamatan dengan data hasil wawancara. Triangulasi dengan metode, maksudnya pengecekan dengan derajat kepercayaan melalui beberapa sumber data dengan metode yang sama. Triangulasi dengan penyidik, maksudnya memanfaatkan peneliti atau pengamat lain, untuk membantu mengurangi kemencengan dan kekiluruan dalam pengumpulan data. Triangulasi dengan teori, maksudnya membandingkan suatu teori dengan teori yang lain. Triangulasi data merupakan pengecekan data terhadap sumber data dengan mengecek kesesuaian sumber data yang diperoleh dengan krakteristik sumber data yang sudah ditentukan penulis, kesesuaian metode penelitian yang digunakan, serta kesesuaian teori yang dipaparkan dalam tinjauan pustaka dengan hasil penelitian. 
Hamlan Andi Baso M., Markarma, \& Munifa

Pendidikan Islam pada Masyarakat Etnik....

\section{Hasil dan Pembahasan}

\section{Pelaksanaan Adat Popene'e dalam Pernikahan Suku Tialo}

Adat memiliki tata cara tersendiri sesuai kesepakatan bersama. Begitu pula dengan pelaksanaan popene'e. Popene'e merupakan hal yang sangat penting dilakukan pada pelaksanaan pernikahan suku tialo. Popene'e ini dilakukan setelah acara inti (akad nikah) dilaksanakan. Popene'e ini dilakukan sehari setelah pernikahan.

Popene'e adalah kunjungan pertama pengantin perempuan kerumah mertuanya (popene'e) bersama pengantin laki-laki. Makna dari adat popene'e ini adalah bukti penghargaan anak kepada orang tua, sekaligus menandai bahwa pihak perempuan sudah merupakan bagian dari keluarga pihak laki-laki/suaminya. Prosesi popene'e merupakan hal yang penting dilakukan pada pelaksanaan pernikahan suku Tialo.

Popene'e artinya menaiki rumah tangga yang baru. Pelaksanaan Popene'e ini memiliki tata cara tersendiri sesuai kesepakatan bersama. Pelaksanaan tersebut dikediaman pihak laki-laki dengan dihadiri oleh keluarga kedua bela pihak untuk bersama-sama menyaksikan pelaksanaan tersebut. Pelaksanaan Popene'e dibagi menjadi 8 tahapan yaitu:

1. Di dalam suku Tialo, Monyambute nu Pangantinge berarti menyambut pengantin. Prosesi ini ditandai dengan penjemputan pengantin perempuan oleh pihak keluarga pengantin laki-laki sebagai tuan rumah. Prosesi tersebut bermakna orang tua laki laki menerima menantunya dengan segenap hati dan mengangapnya sebagai anak sendiri. Dalam prosesi ini pihak laki-laki memberikan parang, pisang dan kelapa kepada pengantin laki-laki yang akan dipikul dan dibawa ke rumah. Hal ini juga merupakan bentuk tanggungjawab seorang suami terhadap istrinya yang terwujud dalam perlengkapan yang digunakan. Perlengkap atau alat yang digunakan adalah parang, kelapa pisang dan batang pohon cengkeh. Makna dari perlengkap atau alat tersebut adalah sebagai berikut: (1), Parang adalah alat yang wajib dibawa oleh masyarakat suku tialo ketika berkebun. Dalam prosesi moyambute nu pangantinge parang merupakan simbol sebagai kewajiban dan tanggungjawab seorang suami yang berarti seorang suami memiliki tugas yaitu mecari nafkah. (2) Kelapa, pisang dan batang pohon cengkeh merupakan simbol nafkah dari suami kepada istrinya. Kelapa yang digunakan adalah kelapa tua makna dari kelapa tua ialah untuk menghasilkan banyak santan yang digunakan sebagai bahan untuk memasak. Dan santan tersebut digunakan oleh istri untuk memasak masakan yang disajikan kepada suami. dan pisang yang digunakan adalah pisang sepatu merupakan sala satu jenis dan variasi buah pisang yang ada di Indonesia, bantuknya cukup besar. Makana dari pisang sepatu tersebut adalah untuk menambah stamina bagi suami istri dalam beraktifitas karena pisang tersebut mengandung berbagai manfaat untuk kesehatan.

2. Di dalam suku Tialo monimbaluse, mombiase niuge kangkai mongkologe, mombiase ayu berarti mengupas, membelah kelapa dan memotong, membelah batang pohon cengkeh. Prosesi ini ditandai dengan pengantin laki-laki mengupas dan membelah kelapa serta memotong dan membelah batang pohong 
cengkeh. Prosesi ini juga merupakan makna kewajiban atau pekerjaan seorang suami untuk mencari nafkah dan merupakan bentuk tanggungjawab seutuhnya suami. Prosesi ini bertujuan untuk mengajarkan tugas sebagai seorang suami.

3. Monesege longu pensae yaitu pengantin perempuan mengiris daun pisang. Prosesi ini merupakan makna kewajiban atau tugas sebagai seorang istri. Alat yang digunakan dalam prosesi ini adalah pisau dan sehelai daun pisang. Makna dari beberapa alat atau perlengkapan tersebut adalah: (1) Pisau merupankan makna dari kewajiban dan tanggungjawab seorang istri yang berarti seorang istri memiliki tugas yaitu memasak. (2) Daun pisang ini merupakan makna dari hubungan dan kewajiban dalam menjalani pernikahan. Pada saat pengantin perempuan mengiris daun pisang, irisan tersebu tidak boleh putus karena pada bagian sisi-sisi daun memiliki makna kerukunan antara keluarga dan suami. hal ini diartikan bahwa seorang istri dapat menjaga hubungan kerukunan keluarga kedua belah pihak dan suami agar kehidupan rumah tangganya sakinah, mawaddah dan warahmah.

4. Mongunjae baki merupakan prosesi menginjak baki oleh kedua pengantin, sebelum memasuki rumah kedua pengantin harus menginjak baki yang terdiri dari parang atau besi dan 3 macam tumbuh-tumbuhan yang diletakkan tepat di depan pintu. Dalam prosesi ini pengantin perempuan yang pertama menginjak baki dan diikuti oleh pengantin laki-laki. Prosesi tersebut bermakna agar dalam kehidupan rumah tangga kedua mempelai sehat, rukun dan berumur panjang. Ketika pengantin menginjak baki orangtua yang dituakan dari pihak pengantin laki-laki membacakan doa. Alat yang digunakan dalam prosesi ini adalah parang/besi dan 3 macam tumbuh-tumbuhan. Makna dari beberapa alat-alat tersebut adalah: (1) Pohon sina guru sebagai simbol obat melambangkan sebuah rumah tangga, (2) Sulampaan adalah tumbuhan yang tumbuh sebagai simbol kesabaran dan obat, (3) siranindi adalah obat kesejukan hati, (4) parang/besi dapat diartikan sebagai simbol kekuatan dan kekokohan dalam pernikahan sebagai perwujudan harapan semoga orang yang menikah tidak akan pernah terpisahkan. Parang/besi yang digunakan berjumlah 1 buah.

5. Di dalam suku Tialo Momba alatu wahu maipa moipa monjaane pensae berari memegang/memyentuh perlengkapan dapur dan memasak. Prosei ini ditandai dengan penganin perempuan menyenuh perlengkapan dapur yang terdiri pisang, air, cerek, belanga, sendok, kayu api dan tungku tanah liat. Prosesi ini merupakan makna kewajiban seorang istri. Prosesi ini bertujuan unuk menghilangkan rasa segan dan kekakua pengantin perempuan untuk melakukan pekerjaan dapur di rumah otang tua laki-laki. Makna dari alat-alat ini adalah penerimaan seorang mertua terhadap menantunya agar kelak seorang menantu dapat ke rumah mertunya tidak lagi merasa canggung.

6. Acara dilanjutkan dengan pembacaan doa selamat oleh salah seorang tokoh agama/imam agar mendapat berkah dari Allah SWT. Dalam acara ini dihidangkan beras ketan putih, sebutit telur rebus, setelah membaca doa selamat, kedua pengantin memakan hidangan tersebut.

7. Prosesi mepaanane merupakan prosesi makan bersama antara penganti laki-laki dan pengantin perempuan dengan saling menyuapi. Prosesi ini merupakan 
makna seiya sekata antara kedua pengantin agar pernikahan selalu baik. Prosesi ini juga merupakan simbol saling mengerti, saling mengisi dan saling bertukar pikiran. Alat yang digunakan dalam pelaksanaan prosesi ini adalah sepiring pisang rebus, kelapa parut, 2 gelas air putih, air cuci tangan serta piring dan sendok untuk makan. Makna dari alat yang digunakan tersebut adalah alat-alat tersebut merupakan simbol kebersamaan kedua pengantin dalam membina rumah tangga.

8. Sebagai akhir dari acara proses popene'e dilakukan acara sujud (sungkeman) dari kedua pengantin kepada keluarga pengantin laki-laki. Dimulai dari kedua orang tua laki-laki, saudara kandungnya, paman, dan bibi dari pengantin lakilaki. ${ }^{15}$

\section{Nilai-nilai Pendidikan Islam Adat Popene'e dalam Pernikahan Suku Tialo}

Secara umum dapat dikatakan bahwa relevansi adat popene'e dalam pernikahan suku tialo mengandung nilai-nilai pendidikan Islam yang sangat besar manfaatnya dalam menempuh suatu rumah tangga yang sakinah mawadah warahma. Namun, penulis secara sederhana mengelompokkan kedalam empat bagian yaitu nilai-nilai pendidikan yang memuat nilai tauhid, syaraiat, akhlak, dan sosial.

Dalam tahapan adat popene'e suku tialo pendidikan yang bernilai tauhid dan syaraiat dapat dijumpai pada tahap satu, dua dan tiga dari ke delapan tahap yang ada. Sedangkan tahap ketiga, empat, lima, enam, tujuh, dan kedelapan, mengandung nilai-nilai pendidikan islam yang arahnya pada pembinaan kehidupan yang bernilai tauhid, akhlak dan sosial yang harmonis.

Pelaksanaan tahapan pertama dalam proses Monyambute $\mathrm{Nu}$ Pangantinge inilah yang menurut penulis mengandung nilai-nilai tauhid dan syariat yang begitu tinggi dan suci dalam proses kehidupan selanjutnya. Hal tersebut penuturan tokoh adat di kecamatan tomini. ${ }^{16}$

Aminudin adalah tokoh adat di Kecamatan tomini mengatakan, bahwa tahapan adat popene'e suku tialo banyak mengandung nilai-nilai pendidikan Islam dan unsur pengajaran. Diantaranya ada nilai tauhid, syariat, akhlak dan sosial. ${ }^{17}$ Adapun menurut penulis bahwa adat popene'e suku tialo ini sangat menonjol bagi masyarakat di Kecamatan Tomini karena adat popene'e suku tialo ini banyak mengajarkan tentang bagaiman cara menanamkan akhlak kepada kedua pengantin tersebut.

Hal demikian dipertegas lahi oleh Suir dan Kamarudin menurut merekan, nilai pendidikan bernuangsa keagamaan sangat menonjol dalam tahapan adat popene'e suku tialo. Selain itu unsur sosial kemasyarakatan nampak sekali. Misalnya, pada acara popene'e tersebut semua masyarakat ikut bergotong royong untuk membantu. ${ }^{18}$

\footnotetext{
${ }^{15}$ Aminudin, Kepala Adat, "Wawancara, 13 Juni 2019

16 Aminudin, Kepala Adat, "Wawancara” 13 Juni 2019

17 Aminudin, Kepala Adat "Wawancara” 13 Juni 2019

${ }^{18}$ Suir dan Kamarudin selaku Imam, “Wawancara” 14 Juni 2019
} 
Tahapan kedua dalam prosesi adat popene'e suku tialo yaitu Monimbaluse, Membiase Niuge Kangkai Mongkologe Ayu (mengupas, membela kelap dan membela kayu). tahapan kedua ini mengandung nilai-nilai pendidikan islam yaitu nilai tauhid, syariat dan sosial dimana tahapan ini pengantin laki-laki berkewajiban untuk memberikan nafka kepada istrinya dan sekaligus bentuk tangung jawab kepada keluarganya dan juga menjadi imam dalam sebuah rumah tangga yang telah mereka bangun. Adapun nilai sosialnya adalah mereka harus memberitahukan kepada orang terdekat, tetanga, dan handai tolan agar dalam prosesi ini adat popene'e ini berjalan dengan lancar.

Menesege Longu Pensa'e (mengiris daun pisang) tahap ketiga ini mengandung nilai-nilai pendidikan tauhid, syariat dan akhlak pada tahapan ke tiga ini pengantin perempuan berkewajiban mengurus suami dan anak-anaknya, bertangungjawab kepada keluarga dan juga harus memcontohkan akhlak kepada anak-anaknya agar tidak melanggal aturan hukum. ${ }^{19}$

Tahapan keempat yakni Mongunjae Baki (Menginjak Baki) mengandung nilainilai pendidikan Islam yaitu nilai tauhid dan syariat dimana prosesi ini mengandung nilai kehidupan berumah tangga selalu sehat, rukun dan berumur panjang. ${ }^{20}$ Tahap kelima yaitu Momba Alatu Wahu Maipa Monjaane Pensae (memegang/menyentuh alat dapur dan merebus pisang) tahap ini mengandung nilai-nilai pendidikan Islam yaitu nilai akhlak di mana seorang istri harus menghargai mertuanya dan seorang istri tidak segan dan tidak takut untuk melakukan pekerjaan di rumah mertua.

Tahapan keenam yaitu Pembacaan Do'a tahap ini mengandung nilai-nilai pendidikan Islam yaitu nilai tauhid, syariat, dan sosial dimana tokoh agama, adat, dan masyarakat membaca doa keselamatan terhadap kedua pengantin agar rumah tangga mereka mendapat berkah dari Allah Swt. ${ }^{21}$

Tahap ketujuh yaitu Mepaanane tahap ini mengandung nilai-nilai pendidikan Islam yaitu nilai akhlak yaitu menghormati suami dan juga suami menghormati istri agar rumah tangga yang mereka jalani bisah berkah di duni dan akhirat. Tahap terakhir atau tahap kedelapan yaitu Sungkeman tahap ini mengandung nilai-nilai pendidikan Islam yaitu nilai akhlak yaitu menghormati kedua orang tua pihak lakilaki dan juga keluarganya.

Berdasarkan penjelasan tersebut diatas, maka pendidikan Islam memiliki fungsi sebagai pembimbing, pengarahan perkembangan, dan pertumbuhan manusia. Jika dicermati lebih jauh tentang perkembangan kebudayaan masyarakat maka akan ditemui betapa besar pengaruh pendidikan utamanya pendidikana Islam dalam prosesi budaya tersebut. Dengan pemikiran diatas, dapat dikemukanan bahwa adat Popene'e ini adalah sala satu kebudayaan yang sangat erat dengan nilai-nilai pendidikan Islam yang memiliki fungsi dalam perkembangan kehidupan manusia.

Bila dilihat dari sisi pendidikan Islam, adat Popene'e suku tialo ini sangat relevan dengan ajaran Islam yang bersumber dari Al-qur'an dan Hadits. Sumber ajaran tersebut sangat erat dengan konsep pendidikan atau ajaran Islam dalam adat Popene'e suku tialo dan dilatar belakangi oleh sejarah Kecamatan Tomini. Relevansi

\footnotetext{
${ }^{19}$ Suir, imam "Wawancara” 13 Juni 2019

${ }^{20}$ Aminudin, Kepala Adat "Wawancara" 15 Juni 2019

${ }^{21}$ Aminudin, Kepala Adat "Wawancara” 15 Juni 2019
} 
antara keduanya tergambar dalam setiap tahapan pelaksanaan adat Popene'e suku Tialo yang berju delapan tahap. Setiap tahap mengandung pendidikan yang sudah tentu bernuansa Islami. Dapat dikemukanakn beberapa contoh antara lain pada tahap pertama yaitu Monyambute Nu Pangantinge (menyambut pengantin).

Bila diteliti secara jelas merupakan implementasi ajaran Al-qur'an dan Hadits mengenai proses popene'e Tahapan pertama yakni Monyambute $\mathrm{Nu}$ Pangantinge (menyambut pengantin). Prosesnya ini mengikuti adat suku tialo di kecamatan tomini. tahapan kedua merupakan proses monimbaluse, mombiase niuge kangkai mongkologe, mombiase ayu berarti (mengupas, membelah kelapa dan memotong, membelah batang pohon cengkeh). Kewajiban bagi suami terhadap istri, tahap ketiga Monesege longu pensae yaitu pengantin perempuan mengiris daun pisang. Prosesi ini agar kehidupan rumah tanga kedua mempelai rukun dan damai. Tahap keempat Mongunjae baki merupakan prosesi menginjak baki oleh kedua pengantin, prosesi ini ialak kewajiban dalam kehidupan rumah tangga kedua mempelai rukun dan sehat. Kelima adalah Momba alatu wahu maipa moipa monjaane pensae berari memegang/memyentuh perlengkapan dapur dan memasak, prosesi ini adalah kewajiban seorang istri. Keenam Pembacaan Doa Selamat prosesi ini ialah agar rumah tangga mereka mendapat berkah dari Allah Swt. Tahap ketujuh Mepaanane prosesi ini adalah suami dan istri saling mengerti. Tahap terakhir adalah sujud (sungkeman) adalah menghormari pihak keluarga dali laki-laki.

Dari penjelasan diatas, nilai-nilai pendidikan Islam yang menjadi acuan bagi hidup manusia adalah sumber nilai Islam. Sumber nilai islam yang dimaksud berasal dari nilai yang menjadi filsafat hidup yang dianut oleh pelaku pendidikan Islam, sumber nilai agama yang pokok adalah Al-qur'an dan As-sunnah.

Adat telah melambangkan dalam kehidupan masyarakat baik berupa tradisi, adat upacara dan lain-lain yang mampu mengendalikan perilaku warga masyarakat dengan perasaan senang atau bangga, dan peranan tokoh adat yang menjadi tokoh masyarakat menjadi cukup penting.

Pernikahan bukan hanya hubungan antara dua bela pihak akan tetapi juga ada nilai -nilai pendidikan Islam didalam tradisi pernikahan adat suku tialo popene'e itu sendiri. Pernikahan merupakan ikatan sosial antara laki-laki dan perempuan yang akan membentuk hubungan untuk mencapai tujuan yang bik sesuai dengan syariat islam demi terciptanya keluarga sakinah, mawaddah dan warahma. Pernikahan merupakan suatu cara yang ditetepkan oleh Allah SWT sebagai jalan bagi manusia untuk beranak, berkambang biak dan menjaga kelestarian hidupnya, setelah masing-masing pasangan siap melakukan peranya yang positif dalam mewujudkan tujuan perkawinan.

Hubungan antara keluarga laki-laki dan perempuan terdapat berbagai macam nilai pendidikan Islam salah satunya yaitu nilai kesetiaan. Maksudnya adalah seorang suami harus menghargai seorang istri begitupun sebaliknya, agar supaya hubungan keduanya bisa bahagia dunia dan akhirat. 


\section{Simpulan}

Berdasarkan hasil penelitian dan pembahasan tersebut. Maka, dapat peneliti simpulkan 2 (dua) hal sebagai berikut:

1. Adat Popene'e dalam Pernikahan Suku Tialo di Kecamatan Tomini dilakukan beberapa tahap yaitu: (1) Monyambute nu Pangantinge berarti menyambut pengantin. Prosesi ini ditandai dengan penjemputan pengantin perempuan oleh pihak keluarga pengantin laki-laki sebagai tuan rumah. (2) monimbaluse, mombiase niuge kangkai mongkologe, mombiase ayu berarti mengupas, membelah kelapa dan memotong, membelah batang pohon cengkeh. Prosesi ini ditandai dengan pengantin laki-laki mengupas dan membelah kelapa serta memotong dan membelah batang pohong cengkeh. (3) Monesege longu pensae yaitu pengantin perempuan mengiris daun pisang. Prosesi ini merupakan makna kewajiban atau tugas sebagai seorang istri. Alat yang digunakan dalam prosesi ini adalah pisau dan sehelai daun pisang. (4) Mongunjae baki merupakan prosesi menginjak baki oleh kedua pengantin, sebelum memasuki rumah kedua pengantin harus menginjak baki yang terdiri dari parang atau besi dan 3 macam tumbuh-tumbuhan yang diletakkan tepat di depan pintu. (5) Momba alatu wahu maipa moipa monjaane pensae berari emegang/ memyentuh perlengkapan dapur dan memasak. Prosei ini ditandai dengan penganin perempuan menyenuh perlengkapan dapur yang terdiri pisang, air, cerek, belanga, sendok, kayu api dan tungku tanah liat. (6) Acara dilanjutkan dengan pembacaan doa selamat oleh salah seorang tokoh agama/imam agar mendapat berkah dari Allah SWT. Dalam acara ini dihidangkan beras ketan putih, sebutit telur rebus, setelah membaca doa selamat, kedua pengantin memakan hidangan tersebut. (7) mepaanane merupakan prosesi makan bersama antara penganti laki-laki dan pengantin perempuan dengan saling menyuapi. Prosesi ini merupakan makna seiya sekata antara kedua pengantin agar pernikahan selalu baik. (8) Sebagai akhir dari acara proses popene'e dilakukan acara sujud (sungkeman) dari kedua pengantin kepada keluarga pengantin laki-laki. Dimulai dari kedua orang tua laki-laki, saudara kandungnya, paman, dan bibi dari pengantin laki-laki.

2. Nilai-nilai pendidikan Islam dalam adat pernikahan popene'e suku Tialo Nilainilai pendidikan islam dalam adat pernikahan popene'e suku tialo ini mengandung beberapa nilai diantaranya nilai tauhid, syariat, akhlak, dan nilai sosial. ke empat nilai tersebut ada dalam adat pernikahan popene'e suku tialo di kecamatan tomini. Adat pernikahan popene'e suku tialo sangat relevan dengan ajaran Islam yang bersumber pada Al-Qur'an dan hadist. Sangat berkaitan dengan konsep pendidikan atau ajaran Islam dalam adat pernikahan popene'e suku tialo dilatar belakangi oleh sejarah awal mula keberadaan Islam di wilayah Kecamatan Tomini. Tahapan pertama sampai akhir menurut penulis tidak bertentangan dengan pendidikan agama Islam relevansi diantara keduanya tergambar dalam setiap tahapan pelaksanaan adat pernikahan popene'e suku Tialo tang berjumlah lima tahap. Menurut pandangan pendidikan agama Islam adat pernikahan popene'e suku tialo ini adalah mengacuh pada konsep-konsep nilai-nilai pendidikan islam yang dikemas 
sedemikian rupa dalam bentuk adat istiadat dengan tidak meningalkan landasan Al-Qur'an dan hadist.

\section{DAFTAR PUSTAKA}

Sjarkawi, Pembentukan Kepribadian Anak, (PT Bumi Aksara, 2008)

Rukaiyah M, Konsep Nilai dalam Pendidikan Islam, (Padangsidimpuan: Makalah STAIN Padangsidimpuan, 2006).

Chalijah Hasan, Dimensi-Dimensi Pendidikan, (Surabaya: Al-Ikhlas)

Achmadi, Tujuan Pendidikan Islam, (At-Tadzkiyyah: Jurnal Pendidikan Islam, 6 November 2015).

Imam Syafe $\mathrm{e}$, " tujuan pendidikan islam” ( At-Tadzkiyyah : Jurnal Pendidikan Islam, vol 6, November 2015).

Said Agil Husin Al Munawar, Aktualisasi Nilai-nilai Qur'an Dalam Sistem Pendidikan Islam, (PT Ciputat Press, 2005).

Adil Abdul Mun'im Abu Abbas, Ketika Menikah Jadi Pilihan (Jakarta: Almahira, 2001) 9.

Amir Syarifuddin, Hukum Perkawinan Islam di Indonesia, antara Fiqh Munakahat dan Undang-Undang Pekawinan (Jakarta: kencana, Cet. III, 20o9).

Khairil Mayah, Adat Pernikahan Suku Tialo (diposting 2 Juni 2016 05:32) http://id.wikipedia.org/wiki/Suku-Tomini diakses (8 Desember 2018), Jam o1:00

Arifuddin, S., \& Palu, K. B. T. T. (2019). Makna Simbolik Dalam Prosesi Popene'e Suku Lauje Di Desa Tomini Utara Kec. Tomini Kab. Parigi Moutong. Jurnal Bahasa dan Sastra, 4(1).

Andi Prastowo, "Metode Penelitian Kualitatif" (Jogjakarta: AR-RUZZ MEDIA 2016), 21

Aminudin, Kepala Adat, "Wawancara, 13 Juni 2019

Suir, imam "Wawancara" 13 Juni 2019 